\title{
Islamic excellence achievement spirit: a strategy to drive knowledge sharing behaviour and adaptive selling capability
}

\author{
Ken Sudarti ${ }^{*}$, Wasitowati \\ Faculty of Economics, Universitas Islam Sultan Agung, Semarang, Indonesia \\ *Corresponding author: kensudarti@unissula.ac.id
}

\begin{abstract}
Knowledge sharing is still becoming a concern for many researchers because of the various positive impacts encountered. However, many individuals are still hesitant to do so, especially in a competitive environment where 'knowledge is power'. Knowledge sharing is often conducted only for the purpose of self-imaging and mutual benefits. Various studies that try to explore the antecedent variable of knowledge sharing behavior rarely use an Islamic motivational perspective. Hence, this article offers a new concept of Islamic excellence achievement spirit which is expected to be a cornerstone to improve knowledge sharing behavior. This new concept is the result of synthesis from the need for achievement theory, social capital theory, and Islamic values. The 291 sharia insurance employees in Indonesia were used as respondents of this study. Respondents obtained by using snowball sampling combined with purposive sampling. Regression analysis is used to test the empirical research model. The results show that Islamic excellence achievement spirit is proven to be able to increase knowledge sharing behavior that has an impact on increasing adaptive selling capability.
\end{abstract}

Keywords: Knowledge Sharing Behavior, Islamic Excellence Achievement Spirit, Adaptive Selling Capability. JEL Classification Code: D83, I31, J24 DOI: 10.20885/jsb.vol25.iss1.art4

\section{Introduction}

Knowledge sharing is a part of knowledge management. Knowledge management has been recognized as an important tool for creating a competitive advantage (Haldin-Herrgard, 2000). In uncertain economic conditions, the most robust resource is knowledge (Nonaka \& von Krogh, 2009). Companies that implement knowledge management have better performance (Pathirage, Amaratunga, \& Haigh, 2007).

Knowledge is a very valuable resource. Its intangible nature makes it unique, rare, and difficult to imitate. Thus, tacit knowledge by individuals needs to be transferred to other individuals through knowledge sharing activities to ensure that the organization still maintains valuable knowledge. Tacit knowledge is knowledge inherent in individuals, one of which is gained from experience. This means, if the individual leaves the organization, the consequence is that knowledge will also be lost along with the individual so that it will harm the organization. Therefore, various efforts undertaken by the organization including increasing knowledge sharing behavior aim to maintain valuable tacit knowledge so that it becomes a strategic asset for organizational development.

Although knowledge sharing behavior is important, many individuals are still hesitant to do so, especially in a competitive environment where 'knowledge is power' (Ling, 2011). Faraj (2005) states that individuals are intrinsically motivated to share knowledge if they believe that what they do can help others solve problems. This is based on their concern and pleasure in helping others. On the other hand, (Faraj, 2005) also believed that one of the reasons that allow someone to be willing to share their knowledge is for self-imaging purposes. This self-image is defined as an individual's perception that sharing knowledge with others will lead to an increase in social status and higher recognition in organizations. Even a study conducted by Swift, Balkin \& Matusik (2010) states that individuals are willing to do knowledge sharing just to enhance the reputation and expect reciprocal 
Islamic excellence achievement spirit: a strategy to drive knowledge sharing

behaviour and adaptive selling capability

behavior such as increasing productivity, assisting in completing their work more effectively, helping to maintain their work, facilitating development their personal and career development (Ling, 2011). Reciprocal behavior is recognized as an important motivation in facilitating knowledge sharing (Hew \& Hara, 2007; Kumar \& Rose, 2012).

Considering the importance of knowledge sharing on the one hand and individual reluctance to do so, many studies have tried to explore the factors that influence an individual's willingness to do knowledge sharing, such as knowledge resources and team participation (Zhanga \& Begleyb, 2011); knowledge-oriented leadership (Donate et al., 2015), absorptive capacity (Song, 2014) and trust (Pinjani \& Palvia, 2013). However, from the existing studies, it is still very rarely related to motivation based on Islamic values (intention to worship). Individuals who do knowledge sharing as a worship interpret reciprocal transactions as a reward from God, just want to seek the pleasure of Allah SWT. Allah SWT said: "I did not create the Jinns and Men only to worship Me" (Holy Qur-an. Az-Dzariat:56). Islamic values teach us to share knowledge, because the knowledge possessed is only an intermediary and not fully our own, there are other people's rights in it. If this belief is owned by each individual, then knowledge sharing behavior as part of the knowledge creation process will produce new knowledge to enable individuals, including increasing adaptive selling capability.

Therefore, this study tries to fill the gap of knowledge sharing behavior by offering a new concept of Islamic excellence achievement spirit. The concept of Islamic excellence achievement spirit is the result of the synthesis of the need for achievement theory, social capital theory, and Islamic values. This new concept will be tested on Islamic insurance salespeople. In marketing policy, the sales team plays an important role in introducing products and increasing market share. Salespeople often have to deal directly with customers who have different and changing requests every time, so they must be able to adjust their sales methods responsively. Therefore, they must master a variety of sales knowledge, one of which can be obtained through knowledge sharing activities.

The new concept of Islamic excellence achievement spirit is defined as the spirit of the individual to do the best work activities and make continuous improvements while asking and helping colleagues to be willing and able to do their best. IEAS has 4 (four) dimensions: doing the best spirit, continuous improvement spirit, da'wah (calling for a good deed) spirit, and helping others spirit. The first two dimensions are the spirit of self-empowering which is the individual's maximum effort to increase his potential, while the other two dimensions are the spirit of empowering others. This is a manifestation of individual concern for colleagues so that they are willing and able to do the best together.

This concept is unique and comprehensive. This uniqueness is reflected, first, from the time dimension that is the world and the hereafter. Individuals who have Islamic excellence achievement spirit are eager to do their best because of the intention to worship. They believe that what they get in the world is only as an intermediary for their lives in the hereafter. In the Holy Qur'an (AlBaqarah: 148), it has been explicitly stated that every Muslim is obliged to be steadfast in doing good. Second, the spirit of becoming better would not end when performance standards have been met, rather it continues to strive to make a continuous improvement. Third, to achieve the best performance, coworkers are not considered as competitors that must be turned off, but rather are considered partners and objects of benchmarking. Fourth, individuals who have an Islamic excellence achievement spirit not only think about themselves but also ask and help colleagues to be willing and able to do good. Based on this uniqueness, this concept is expected to be able to increase knowledge sharing behavior among sales team members. Thus, tacit knowledge inherent in each sales team member can be optimized for broader benefit. The results of this study are also expected to be able to enrich scientific knowledge, especially Needs for Achievement Theory, Social Capital Theory, and Knowledge Management. 


\section{Literature Review}

\section{A Concept Mapping of Islamic Excellence Achievement Spirit (IEAS)}

Islamic Excellence Achievement spirit is individual behavior that is associated with personal religious values, especially Islam. A good Muslim is one who can carry out his work by not merely seeking appreciation, but rather worshiping Allah (Zahrah, Norasyikin, Hamid, Huda, \& Rani, 2016). Devout Muslims are those who make the Qur'an and Al-Hadith as the world of life. In al-Qur'an, there is an order to compete in good (fastabiqul khoirat) (Holy Qur'an. Al-Baqarah: 148). Individuals with a high spirit of fastabiqul khoirat will do continuous learning to improve their best performance. Islamic excellence achievement spirit is the spirit of achieving good continuously. Continuous improvement continues to be pursued to adjust to environmental changes because God will not change the condition of people if they do not try to change by themselves (Holy Qur'an.ArRa'd:11). Continuous improvement is an endless gradual change focused on increasing effectiveness and/or efficiency. In this case, improvement is based on small changes rather than radical changes (Elias \& Davis, 2018). Individuals with high learning orientation will open themselves to new thoughts, be willing to interact with the external environment, and dare to take risks. Learning orientation will increase innovation (Calisir, Altin Gumussoy, \& Guzelsoy, 2013).

Individuals with Islamic excellence achievement are eager to do their best. The spirit of doing the best is different from what has been defined in the need for achievement theory by some previous researchers, such as (Lindgren, 1976) which states that individuals with a high need for achievement want to succeed in competitive situations and want to prove their superiority over others without regard to ostracized by less successful coworkers. Ward \& Dranove (1995) state that individuals with a high need for achievement prefer competitive strategies rather than cooperatives. Soyer, Rovenpor, \& Kopelman (1999) state that individuals who want to achieve the highest results are ambitious. Khan, Breitenecker, \& Schwarz (2015) used several dimensions to measure the need for achievement; taking the opportunity to develop themselves, taking on more challenging responsibilities, targeting new projects that were more interesting, and challenging themselves to produce the best work.

Individuals with high Islamic excellence achievement spirit perform work activities that are best in accordance with their resources and the intention to worship. The best performance is to be achieved by using resources efficiently, not israf (wasteful), and does not make a doubtful prediction over something (Holy Qur'an.Al-Isra':26-27). Professionalism is used as a measure of work because God sees everything he does. However, realizing that their resources are limited, not superior in everything, they do not hesitate to do partnerships with colleagues as part of maximizing efforts to achieve the best. The collaboration will improve performance (Chen, Lin, \& Yen, 2014).

Individuals with high Islamic excellence achievement spirit care about the achievements of their colleagues. They aware that they work in a team consisting of individuals with different capacities and enthusiasm, reinforce their desire to do da'wah (preaching), invite their colleagues to want to optimize their resources. Allah SWT said in Holy Qur'an (Al- 'Asr: 2-3) that "indeed man is in a state of loss, except for those who believe and work on virtue and advise one another for truth and patience". Da'wah is delivered with patience and affection (Holy Qur'an, Al-Balad:17-18; Al'Asr:1-3). Da'wah activities are conducted by using good language. The good language will make communication more effective. Yen, Wang \& Horng (2011) stated that effective communication will influence trust. Willingness to do da'wah because of the spirit of togetherness that exists between team members makes them willing to accept critical thinking, hope for reciprocity, and cooperation (Yu, Hao, Dong \& Khalifa, 2013).

Individuals with high Islamic excellence achievement spirit prepare themselves as role models so that their da'wah content can be accepted. Wu (2007) states that the character of the message provider will influence the perception and evaluation of the information conveyed. If a colleague experiences difficulty, individuals with high Islamic excellence achievement spirit are 
Islamic excellence achievement spirit: a strategy to drive knowledge sharing

behaviour and adaptive selling capability

willing to help without being asked even if it is not their main task. Olowookere \& Adekeye (2016) states that someone with high religiosity tends to do additional work outside of their obligations and has a strong commitment to the goals of the organization.

\section{Islamic Excellence Achievement Spirit and Knowledge Sharing Behavior}

Motivation has been recognized as a key factor in the success of knowledge in an organization (Swift et al., 2010). However, the motivation used to increase knowledge sharing is often limited to worldly intrinsic and extrinsic motivation (Mosala-, Hoskins, Africa, \& Mosala-bryant, 2016) and ignores religious factors. The worship motivation will be stronger because someone who believes that whatever is done is always supervised by God, so this motivates them to do their best (Zahrah et al., 2016; Holy Qur'an.Al-Furqon:67). Someone who wants to do their best will work their best.

The process of knowledge sharing is conceptualized as two dimensions; knowledge donating and knowledge collecting. Knowledge donating is defined as the process of individuals communicating their intellectual capital to others, while knowledge collecting is defined as the process of gathering knowledge from various sources as their intellectual capital (Lin \& Lin, 2007). The more knowledge sharing activities are carried out, the more knowledge can be explored and the greater the benefits for individuals and organizations.

Worship motivation is very important as a basis for doing work. The intention of worship encourages salespeople to devote all of its resources. But they realize that their resources, including knowledge, are very limited (Holy Qur'an.Al-Kahf:109). Thus, they need renewal and additional knowledge through collaboration (Chen et al., 2014) in the form of knowledge sharing. A devout Muslim strongly believes that the existing knowledge of himself is only as wasilah (something that brings someone close to God), not absolute ownership but contains the rights of others. This belief increases his interest in sharing knowledge, the more knowledge is shared, the more knowledge will get and also will provide mutual benefits (Lin \& Lin, 2007). This mutual benefit is not only transactional worldly, but the positive effects of every good action will be felt in the afterlife. Hence, the greater a person's desire to do their best, the more eager they do knowledge sharing. The orientation towards resource efficiency increases his desire to allocate his resources only to positive things so that he is more enthusiastic in collecting knowledge through knowledge sharing.

In conclusion, the individuals who have the enthusiasm to do the best work activities will increase their intensity in finding the latest information that is relevant to their work to ensure that what they do meets the best standards. Resources are only focused on important activities to support the achievement of the best work quality. This directs the behavior to share only quality knowledge. The foundation of religious values increases his enthusiasm for intensive knowledge sharing without worrying about being harmed. Therefore, the hypothesis proposed is:

H1: Do-the-best spirit will have a positive correlation with knowledge sharing behavior

Individuals who have an Islamic excellence achievement spirit will always make continuous improvement. They are not satisfied with their current performance because they believe that the best indicators are dynamic. The concept of continuous improvement is briefly interpreted as "getting better all the time" (Fryer, Antony, \& Douglas, 2007). Continuous improvement is an endless gradual change focused on increasing effectiveness and/or efficiency. In this case, improvement is based on small changes rather than radical changes (Elias \& Davis, 2018).

To be able to make changes, it requires input and additional knowledge as material to make improvements. By conducting intensive knowledge sharing with the members of sales team, a lot of information is obtained as a basis for comparison and improvement of activities in the future. The search for knowledge continues to be pursued because religion forbids humans to despair (Holy Qur'an.Az-Zumar:53), today must be better than yesterday and tomorrow must be better than today. Individuals who have a spirit of continuous improvement realize that no human is perfect, but as humans, they must strive towards perfection. To get to perfection, others are needed as a 
refinement through benchmarking. Benchmarking is increasingly popular as a tool for continuous improvement (Elmuti \& Kathawala, 1997). Benchmarking can be done through internal and external processes. For internal processes, benchmarking can be done through knowledge sharing (Elmuti \& Kathawala, 1997). Thus, the enthusiasm for continuous improvement will encourage individuals to continue to dig up information, discuss in search of more efficient and effective ways, and brainstorm to sharpen environmental analysis. Brainstorming makes them aware of each other's strengths and weaknesses and takes lessons from past successes and failures as a basis for further improvement.

In conclusion, individuals who work in a team will be eager to make continuous improvement and are always looking for the latest information through knowledge sharing activities. Religious values make him aware that humans are not perfect, so directing their behavior to work together with others in finding new insights through discussion and brainstorming so that their work will be almost perfect. The ability to take lessons from past successes and failures increases his enthusiasm to always share experiences. Thus, the hypothesis proposed is:

H2: The continuous improvement spirit will have a positive correlation with the knowledge sharing behavior.

The third dimension of Islamic excellence achievement spirit is "da'wah spirit". This dimension is derived from relational social capital with the indicator of the cooperative norm. Cooperative norm is defined as a willingness to respond to diversity and appreciate openness to critical thinking, the hope of reciprocity, and cooperation (Yu et al., 2013). Individuals who have this kind of spirit have a high concern (empathy) towards their coworkers so that they are enthusiastic in delivering da'wah (preaching) so that their coworkers are willing to do the best work activities. People who have high empathy are more willing to listen to the complaints of the interlocutors (Itani \& Inyang, 2015). They believe that he and his colleagues are one unit, so they must advise one another in kindness. Thus, they will not lose (Holy Qur-an. Al-Asr:1-3). This spirit of togetherness can be known as social identification that fosters one's motivation to share knowledge. On the contrary, different and contradictory identities in the community form obstacles to sharing knowledge (Nahapiet, 2013). Yu et al. (2013) assert that emotional ties with a group give rise to motivational forces that lead to collective action and readiness to engage in interaction. Someone more willing to share knowledge with those who have the same attitude, philosophy, and experience and tend to agree with them (Holste, 2010). Otherwise. the perceived lack of commonality prevents individuals from engaging in sharing knowledge with their peers. Thus, individuals are more likely to share knowledge when they believe that they are the same or are cognitively equivalent (Zagenczyk, Scott, Gibney, Murrell, \& Bennett, 2010).

In the context of Islamic excellence achievement spirit, individuals who have the da'wah spirit try to set an example first before asking coworkers to do their best. The ability to give examples will create trust. Like a preacher who always spread goodness, has the task of convincing sales team members to want to do what he teaches. The Prophet Muhammad saw said: "Whoever gives an example of good deeds, he will get the reward of these actions as well as the reward of those who follow him, without reducing their reward at all" (Narrated by Ahmad). The higher the trust, the more willing to do knowledge sharing. They believe in each other that the knowledge they share is not to defeat each other. The relationship of trust has been chosen as an important factor in the relational dimension of social capital (Inkpen \& Tsang, 2005) and as one of the variables most often used to realize knowledge sharing (Nahapiet, 2013).

In conclusion, if individuals are in teamwork that has an identity, their emotional ties create motivation for sharing knowledge. A sense of togetherness will foster affection between individuals that will lead them in maintaining a positive relationship between trust and da'wah. Da'wah activities are closely related to communication that lead to interactive behavior to share knowledge. Based on the literature review, the hypothesis proposed is: 
H3: The da'wah spirit will have a positive correlation with the knowledge sharing behavior.

The fourth dimension of Islamic excellence achievement spirit is helping others. Individuals, who have the spirit to help others, are eager to help his colleagues in kindness. They realize that as social beings, they cannot live alone. Fellow Muslims are like buildings that are tiled, complementary, and mutually reinforcing. The resources owned by each individual are very limited and imperfect. Helpful activities can be realized in anything, including helping to increase knowledge and improve skills or conduct joint visits. Through knowledge sharing activities, members of teamwork can exchange their experiences.

In the perspective of Islamic excellence achievement spirit, individuals are eager to help colleagues even though it is not related to their job. They do it sincerely, there is no transaction element. This is due to the cooperative norm which was based on the spirit of togetherness. Cooperative norms in a group include a willingness to appreciate and respond to diversity, openness to critical thinking, and the expectation of reciprocity and cooperation. Shared values in a team will lead to prominent subjective norms about cooperation, namely one's perception of the expectations of team members in terms of sharing knowledge (Orces \& Kim, 2005). Reciprocal relationships embedded in the norms of cooperation provide assurances to team members that the sharing of knowledge they do will be valued both directly and indirectly (Yu et al., 2013).

Someone who has an Islamic excellence achievement spirit will help without being asked and without expecting the rewards. This statement is different from the results of studies by Islam, Jasimuddin, \& Hasan (2015) which concludes that people in an organization believe that "knowledge hoarding" and "fear of losing power". This principle explains the reluctance of individuals to share knowledge with others because they believe that the knowledge that they have acquired is very valuable and is needed for personal gains, such as job security or career development unless there is an element of "reciprocity". For a Muslim, motivation to get a reward is a "reciprocity" measure that drives someone to be more intense in sharing knowledge. A sense of togetherness as a Muslim is a social capital that makes a person more attached to one another and is manifested through the strong intention to help (Yang, Gong, \& Huo, 2011). The results of the study are in line with the statement of $\mathrm{Ng}$ (2005), which confirms that group and organizational behavior plays an important role in facilitating spontaneous behavior such as helping.

In conclusion, individuals who have a passion to help their coworkers to do the best performance, they will make various efforts to understand their coworkers for what they do not know yet. His sincerity to increase his intensity in sharing knowledge is motivated by realizing that the absorbability (capability to absorb/understand knowledge) of each individual is different. Thus, the hypothesis proposed is:

H4: The spirit of helping others will have a positive correlation with the knowledge sharing behavior.

\section{Knowledge Sharing Behavior and Adaptive Selling capability}

Knowledge sharing is an activity where knowledge is exchanged from one person, group, or organization (Campbell et al., 2012). Knowledge sharing is very important in solving problems (Hsu, 2008). Sharing is defined as the process of getting feedback, asking and telling someone what is needed, asking for help to do something in a certain way, and asking why they do it, why they think like that, and so forth. Hence, sharing here is not just about sharing information but the process of wanting to know how and why (Wamitu, 2015).

In short, when individuals intensively exchange the knowledge they have, there will automatically be two-way communication. This knowledge sharing can range from sales knowledge to how to solve customer problems. Through communication activities, the employees know how and why customer problems can occur, so that they can adjust their sales methods based on the current situation and condition. An employee who has an adaptive selling capability can adjust his 
sales methods flexibly (Wong et al., 2015). This capability will increase if the employee intensively and aggressively asks about the sales experience of his coworkers so that the mistakes that his colleagues have experienced will not be conducted again. An employee who has high capability in selling adaptation will be more responsive (Limbu et al., 2016) in changing sales methods if needed. This capability can be sharpened by exploring the success of the experiences of coworkers who face similar problems. Hence, the hypothesis proposed is:

H5: the stronger knowledge sharing behavior, the stronger adaptive selling capability

\section{Emplical Model}

Based on a complete and in-depth literature review, the empirical research model of this research is presented below.

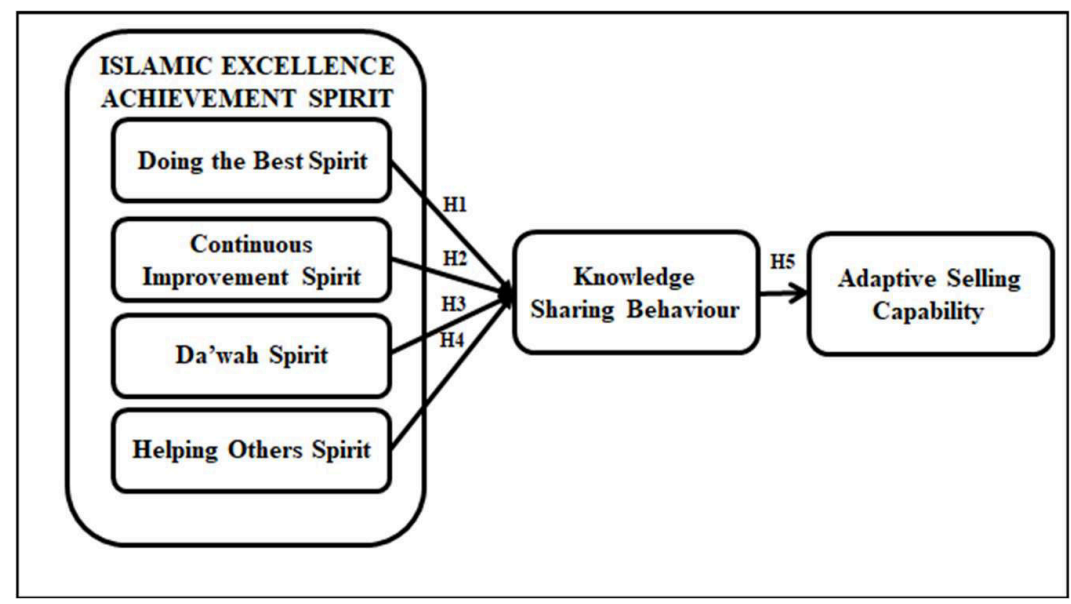

Foure 1. Empirical Research Model

\section{Nethods}

\section{Population, Semples and Deta Colloction}

The employees of 63 sharia insurance companies in Indonesia that were registered at the OJK (Otoritas Jasa Keuangan or Financial Services Authority) in 2018 is the population of this study. For the unit of analysis, this study used salespersons considering that their activities involved sales and service activities (Singh \& Venugopal, 2015). Purchasing service products requires salespersons to have the expertise to help customers make the right choices as customers are sometimes involved in a complex buying decision process, There is a cooperative relationship between sellers and customers, so that repeat sales and referrals are important factors (Saxe, Weitz, \& Weitz, 1982).

The number of parameters to be estimated in this study is 46 parameters, so the minimum number of samples taken is 230 respondents. For the number of samples, this study referred to Hair et al. (2012), which is about 5 times the estimated parameters. Ten companies that are members of IFI that have the best performance according to the FSA in 2018 were selected to determine respondents. A snowball sampling technique with purposive sampling was used as sampling techniques of this study. The characteristics of the respondents included in the criteria are those who have worked as salesperson for at least 1 year and become a member of the sales team.

The data collection method is done by distributing questionnaires and interviews directly with salespeople. The 330 questionnaires were distributed and 298 questionnaires returned (90percent). It can be said that the questionnaires were ready to be processed are 291 answered questionnaires (97.7percent), while 7 others (3.3percent) could not be processed because the data were incomplete. Question items have been through a very strict process and were discussed 
through Focus Group Discussion (FGD). As a final result, 22 closed statement items and some open questions were selected.

Respondents consis of 79 percent men and 21 percent women who were aged between 24 to 48 years old. The majority of education level (63.2 percent) is the undergraduate holders and another 36.8 percent is diploma holders. The working period is dominated by 1 to 5 years $(72.4$ percent) and then followed by those working in a period of 6 to 10 years (22.4 percent). Most of the salespeople are Muslim (93.1 percent) and the rest are Christian and Hindu.

\section{Measurement}

\section{Islamic Excellence Achievement Spirit (IEAS)}

IEAS is defined as the spirit of individuals working in a team, carrying out the best activities, and making continuous improvement. While they are asking and helping colleagues, they would be willing and able to do the best activities. IEAS has 4 dimensions. The first dimension is doing the best spirit measured by using 4 indicators; best performance, professional, optimizing source, and partnership (Khan, Breiteneeker and Scwarz, 2015; Holy Qur'an.An-Najm:39 and Al-Furqon:67). The second dimension is continuous improvement spirit measured by using 4 indicators; long-life learning, better without eliminating others, lessons learned from self-previous experience and observational learning (Khan, Breiteneeker \& Scwarz, 2015; Fryling, Johnston \& Hayes, 2011; (Holy Qur'an. Al-Baqarah: 148 and Al-Maidah:48). The third dimension is da'wah spirit measured by using 3 indicators; da'wah intensity, da'wah communication and da'wah personality (Yu et al., 2013; Holy Qur'an.An-Nisa:9 and As-Saff:2-3). The fourth dimension is helping others spirit which is measured by using 4 indicators; enthusiastic helping others, initiative helping spontaneously, initiative helping without expecting rewards, and initiative helping in extra roles (Olowookere \& Adekeye, 2016; Cardos \& Mone, 2016; Holy Qur'an.Al-Muddassir:6 and Al-Asr:1-3).

\section{Knowledge sharing behavior}

Knowledge sharing behavior is defined as the behavior of salesmen in sharing knowledge with the intention of worship as measured by using 3 indicators; enthusiastic, sincere, and initiative (Murtaza et al., 2016; Obeidat, 2015).

\section{Adaptive selling capability}

Adaptive selling capability is defined as the ability of salesmen to adjust their sales methods based on the situations and conditions encountered that are measured by using 4 indicators: experimental, flexible, modification and responsive (Kaynak et al., 2016; Limbu et al., 2016: Leischnig \& KasperBrauer, 2015; Kara et al., 2013).

All variables were measured by using a 5 Likert scale, where 1 for strongly disagree, 2 for less agree, 3 for neutral, 4 for agree and 5 for strongly agree. The SEM analysis was performed by using AMOS 24.00.

\section{Analysis Techniques}

Regression analysis is used to test the empirical research model as suggested (Ghozali, 2005) Two regression models were established, first, multiple linear regression between doing the best spirit (DBS), continuous improvement spirit (CIS), da'wah spirit (DS), and helping others spirit (HOS) to find out the direct effects of the four constructs on knowledge sharing behavior (KSB). Second, simple linear regression between knowledge sharing behavior (KSB) and adaptive selling capability (ASC). In the first and second regression models, the analysis of the goodness of fit model is determined to determine whether variations in the independent variable can explain the variation of the dependent variable. A model has good goodness of fit model if the F-test produces a p-value 
that does not exceed 0.05 (Ghozali, 2005). Besides, a classic assumption test is also carried out to ensure that the residual value of each model does not experience an abnormal distribution, has an extreme level of correlation, and similarity of variance. The variance inflation factor (VIF) test in multiple regression analysis is also used to explain that there is no multicollinearity in the established regression model. VIFs that do not exceed 10 are considered not to occur multicollinearity in the regression model. The normality test used Kolmogorov-Smirnov Z (K-S) on each model. K-S test that produces a p-value greater than 0.05 indicates a normal data distribution. The similarity of variance (homoscedasticity) was tested by using the Glesjer test. A p-value greater than 0.05 from the Glesjer test results shows that the regression is free from heteroscedasticity (Ghozali, 2005).

\section{Findings}

\section{Reliability and validity}

Investigating the internal consistency of latent variables using Cronbach's alpha $(\alpha)$ requires that all variables in the model exceed the 0.6 thresholds as suggested by Nunnally \& Bernstein (1994). The validity test of each indicator is done by calculating the $\mathrm{p}$-value in the t-test for the correlation coefficient (r) score of indicator items with the total score. A p-value of less than 0.05 indicates high validity. The results of data analysis showed that Cronbach's alpha $(\alpha)$ from all constructs ranged from 0.751 to 0.865 , showing good reliability. Whereas the $p$-value of each indicator which is less than 0.05 shows a very good indicator validity.

Table 1. Construct Validity and Reliability Tests

\begin{tabular}{lccc}
\hline \multicolumn{1}{c}{ Variables and Indicators } & $R$ & $p$-value & $C A(\alpha)$ \\
\hline Doing the Best Spirit (DBS) & & & \\
$\quad$ Best performance & $0.769^{* *}$ & 0.000 & 0.813 \\
$\quad$ Professional & $0.757^{* *}$ & 0.000 & 0.855 \\
$\quad$ Optimizing source & $0.756^{* *}$ & 0.000 & 0.773 \\
$\quad$ Partnership & $0.730^{* *}$ & 0.000 & 0.751 \\
Continuous Improvement Spirit (CIS) & $0.868^{* *}$ & 0.000 & 0.852 \\
$\quad$ Long life learning & $0.875^{* *}$ & 0.000 & 0.865 \\
$\quad$ Better without eliminate others & $0.841^{* *}$ & 0.000 & 0.794 \\
Lesson learn from self-experience & & & \\
Observational learning & & & \\
Da'wah Spirit (DS) & $0.899^{* *}$ & 0.000 & 0.798 \\
$\quad$ Da'wah communication & $0.821^{* *}$ & 0.000 & 0.779 \\
Da'wah intensity & $0.855^{* *}$ & 0.000 & 0.785 \\
Da'wah personality & & & \\
Helping Others Spirit (HOS) & $0.776^{* *}$ & 0.000 & 0.781 \\
$\quad$ Enthusiastic helping others & $0.788^{* *}$ & 0.000 & 0.777 \\
Initiate helping spontaneously & $0.789^{* *}$ & 0.000 & 0.781 \\
Initiate helping without expect return & $0.752^{* *}$ & 0.000 & 0.768 \\
$\quad$ Initiate helping in extra role & & & \\
Knowledge Sharing Behavior (KSB) & $0.898^{* *}$ & 0.000 & 0.784 \\
Enthusiastic & $0.833^{* *}$ & 0.000 & 0.787 \\
Sincere & $0.875^{* *}$ & 0.000 & 0.810 \\
$\quad$ Initiative & & & \\
Adaptive Selling Capability (ASC) & $0.840^{* *}$ & 0.000 & 0.787 \\
Experiment & $0.831^{* *}$ & 0.000 & 0.796 \\
Flexible & $0.855^{* *}$ & 0.000 & 0.757 \\
Modification & $0.871^{* *}$ & 0.000 & 0.712 \\
$\quad$ Responsive & & & \\
\hline
\end{tabular}




\section{Hypothesis Testing Results}

The first model regression test results obtained F-count of 152,371 with a p-value of 0,000 and the second model produces F-count of 128.508 with a p-value of 0,000 . It means, both regression models have good goodness of fit. The results of the normality assumption test using the K-S test on each model showed a significance level of 0.064 and 0.211 , indicating that the residual values in the first and second models were normally distributed. Furthermore, the independent variables in each model also showed no symptoms of heteroscedasticity, which was indicated by the results of the Glesjer test which all showed figures above 0.05. Also, the value of the variance inflation factor (VIF) of the second model in this study is below 10, indicating the model does not occur multicollinearity.

Based on the hypothesis test in the first regression, it showed that DBS $\rightarrow$ KSB $(\beta=0.316$, $p$-value $<0.01)$; CIS $\rightarrow \mathrm{KSB}(\beta=0.287, p$-value $<0.01), \mathrm{DS} \rightarrow \mathrm{KSB}(\beta=0.253, p$-value $<0.01)$, $\mathrm{HOS} \rightarrow \mathrm{KSB}(\beta=0.279, p$-value $<0.01)$. The second regression model shows that $\mathrm{KSB} \rightarrow \mathrm{ASC}(\beta=$ 0.334 , $p$-value $<0.01)$. Based on the results of these calculations, it can be concluded that $\mathrm{H}_{1}, \mathrm{H}_{2}$, $\mathrm{H}_{3}, \mathrm{H}_{4}$ and $\mathrm{H}_{5}$ are supported.

Table 2. Parameter estimate for the path: Direct effects

\begin{tabular}{clcrrrrr}
\hline Hypothesis & Regression & Beta & B & SE & CR & p-value & Results \\
\hline $\mathrm{H}_{1}$ & DBS $\rightarrow$ KSB & 0.316 & 0.352 & 0.072 & 2.556 & 0.001 & Supported \\
$\mathrm{H}_{2}$ & CIS $\rightarrow$ KSB & 0.287 & 0.271 & 0.074 & 2.757 & 0.000 & Supported \\
$\mathrm{H}_{3}$ & DS $\rightarrow$ KSB & 0.253 & 0.291 & 0.083 & 2.857 & 0.002 & Supported \\
$\mathrm{H}_{4}$ & $\mathrm{HOS} \rightarrow \mathrm{KSB}$ & 0.279 & 0.227 & 0.089 & 2.872 & 0.003 & Supported \\
$\mathrm{H}_{5}$ & $\mathrm{KSB} \rightarrow \mathrm{ASC}$ & 0.334 & 0.284 & 0.072 & 2.568 & 0.002 & Supported \\
\hline
\end{tabular}

Model $1:$ Adj R2 $=0.322 ; F=152.371, p$-value $=0.000 ; \mathrm{K}-\mathrm{J} Z=0.84$, $\mathrm{p}$-value $=0.064$

Model 2 : Adj R2 $=0.363 ; F=128.508, p$-value $=0.000 ; \mathrm{K}-\mathrm{J} Z=0.52$, $\mathrm{p}$-value $=0.071$

Note: DBS= Doing the Best Spirit, CIS =Continuous Improvement Spirit, DS = Da'wah Spirit, HOS = Helping Others Spirit, KSB = Knowledge Sharing Behavior, ASC = Adaptive Selling Capability

\section{Discussion}

This study has proven the important role of Islamic excellence achievement spirit by doing the best spirit, continuous improvement spirit, da'wah spirit, and helping others spirit as the encouragement of knowledge sharing behavior. Ultimately, it will bring an impact on the adaptive selling capability. Islamic excellence achievement spirit is proven to be able to overcome doubts of employees in conducting knowledge sharing. This study breaks the conclusion of a study conducted by Ling (2011) that individuals are reluctant to share knowledge in a competitive atmosphere when knowledge is power. This study is also not in line with the statement by Faraj (2005) that one of the reasons that allow someone to share their knowledge is due to self-imaging purposes, to enhance reputation, to expect reciprocal behavior (Swift, Balkin, \& Matusik, 2010) and facilitate personal development and career development (Ling, 2011). The religious values that underlie the Islamic excellence achievement spirit put the intention of worship as the basis for all work actions, so that reward from God is becoming the main goal (Zahrah, Norasyikin, Hamid, Huda, \& Rani, 2016). An employee with high Islamic excellence achievement spirit considers all their resources to be entrusted by God, in which there are other people's rights that must be given.

Doing the best spirit as the first dimension of forming an Islamic excellence achievement spirit (IEAS) is the main capital and the cornerstone of IEAS operation. Religious values convinced him that humans get results according to their efforts (Holy Qur'an.An-Najm:39). Through the best sales achievements, an employee can transmit the best sales methods to coworkers. Sales methods that have succeeded in bringing sales success were told to colleagues as inspiration and material for discussion. The spirit to achieve the best sales activities will guide him to always seek the updated knowledge to ensure that what has been done is in accordance with environmental demands. The 
principles of professionalism and resource efficiency also direct their behavior to provide and obtain quality knowledge through discussions with colleagues. The fair partnership they built did not create an obstacle to re-discuss the best effort in serving customers without worrying about reducing their knowledge. They realize that the knowledge possessed is only entrusted by Allah SWT in which there are other people's rights that must be shared.

The spirit to do continuous improvement spirit has also been proven to increase knowledge sharing behavior. Changes in customer demands are very dynamic, making the employee aware of always updating the latest ways to satisfy customers. To update information, an employee needs to explore the sources of information as many as possible especially from colleagues in the team. Benchmarking is routinely carried out as part of an effort to do sustainable development. Benchmarking can be done through knowledge sharing (Elmuti \& Kathawala, 1997). The spirit to improve sales activities is done by seeking wisdom from past successes and failures, whether done by individuals or colleagues. The spirit of togetherness that exists within the team encourages employee to share their experience with their colleagues, so that no mistakes are repeated. Knowledge sharing forums are held as often as possible to ensure that no information is missed.

Da'wah spirit as one dimension of IEAS has been proven capable of triggering knowledge sharing behavior. Da'wah spirit increased the desire to inform the best-selling method ever. The spirit of togetherness that exists between team members makes them willing to accept critical thinking, mutual hope, and cooperation (Yu, Hao, Dong, \& Khalifa, 2013). The spirit of asking goodness is implemented by being willing to participate in various discussions. The discussion forum was used as a vehicle for the delivery of da'wah. The best sales achievements serve as a case in the discussion because da'wah is about trust. Wu (2007) states that the character of the message provider will influence the perception and evaluation of the information conveyed.

The willingness of an employee to help colleagues is proven to be able to increase the willingness to share knowledge about how to retain customers. Willingness to help show good relationships and facilitate knowledge sharing (Nahapiet, 2013). Identical feelings as a team increase the desire to enable colleagues to achieve sales targets. Individuals are more likely to share knowledge when they believe that they are equal or are cognitively equal (Zagenczyk, Scott, Gibney, Murrell, \& Bennett, 2010). They help coworkers without being asked. The family spirit drives them to help coworkers find new ways to serve customers through joint experiments.

The more employees do knowledge sharing with colleagues, the more information is obtained about how to manage the heterogenous customers. Frequent discussions make the employee better understand how to use various sales methods. Various sales simulations that are practiced in the discussion with colleagues, increase the ability to change sales methods responsively. Customer demands that often change suddenly can be overcame by referring to the similar experiences of coworkers in the past, as basically the events in the field are repetitive.

\section{Managerial Implications}

This study provides several managerial implications related to the research variables. Knowledge sharing behavior as an effort to increase adaptive selling capability can be improved through a staffing process policy in the teamwork by prioritizing core values of employees. Core values that need to be considered are religious values oriented to knowledge sharing behavior. Religious values will make the employee not hesitate to share knowledge because they don't worry about losing power. This policy will form a culture of knowledge sharing and complementarity so that employees will increasingly have a wealth of knowledge about sales. In addition, enrichment of sales knowledge can be done by changing the configuration of team members regularly in order to maximize the exchange of sales knowledge. The sales knowledge that employees acquire from the interactions of previous team members can be carried over to the next team.

To increase knowledge sharing behavior, the organization must increase the Islamic excellence achievement spirit through increasing self-empowerment as a cornerstone. Therefore, 
organizations must choose an employee with good competence as initial capital to meet the best sales activity indicator. Through high competence, employees are more productive (Heskett, Sasser, \& Schlesinger, 1997; Chakrabarty, Widing, \& Brown, 2014). If the employee already has sufficient initial competence, various total human rewards (i.e., training, motivating and giving monetary reward) given by the organization during the internal marketing process will get good feedback in a form of sense of belonging and a better work attitude (To, Martin, \& Yu, 2015). Strengthening the continuous improvement spirit is done by encouraging the employee to continue exploring and applying knowledge about sales strategies through adequate support (physical and non-physical) facilities. Knowledge management practices and policies in an organization can be implemented by forming a community of experts or practitioners. Rozewski (2015) states that knowledge will be more intensive through the community practice networks.

The company strengthens empowering others by encouraging any employees to do da'wah activities through the enhancement of the communication capabilities of each member of the organization. While the strengthening of the "helping" activity is carried out by always propagating that the members of the organization are brothers, so they do not hesitate to share the best-selling methods. Solidarity improvement can be done through reward-based on team performance. Greenfield \& Marks (2007) states that the more identical a member is with his religious group, the more his participation in formal activities increases. Increasing solidarity can be formed through shared values. Rosendaal (2009) states that the more identical a person is with his group, the more willing he is to share knowledge. The more identical a person is to an organization, the more willing he is to sacrifice (Mitchell et al., 2009).

\section{Limitation and Future Research}

This research only focuses on the study of new variables of Islamic Excellence Achievement Spirit (IEAS) that is associated with knowledge sharing behavior and adaptive selling capability. Therefore, there are still several possibilities that can be done for the expansion of research. First, because the R square of the two equations is still below 60percent, other variables outside of IEAS are still needed as levers of knowledge sharing behavior. Several variables that may be considered such as build trust and organizational commitment (Lin \& Lin, 2007), organizational justice (Yesil \& Dereli, 2013), culture (Luu, 2014), collaboration (Chen et al., 2014), social capital (Dijk, Hendriks, \& Romo-leroux, 2016), Organizational Citizenship Behavior (Yoon, 2016), Islamic work ethics (Murtaza et al., 2016) and motivation (Wang \& Hou, 2015). Second, as the IEAS concept is a new concept, it needs to be re-examined on different objects to get a better conclusion.

\section{References}

Calisir, F., Altin Gumussoy, C., \& Guzelsoy, E. (2013). Impacts of learning orientation on product innovation performance. The Learning Organization, 20(3), 176-194. DOI: 10.1108/09696471311328442.

Campbell, B.A., Coff, R. \& Kryscynski, D. (2012). Rethinking sustained competitive advantage from human capital. The Academy of Management Review (AMR), 37(3), 376-395.

Cardoș, R. A. I. \& Mone, I. S. (2016). Religiousness, Spirituality And Work Values: A Step Forward For Work-Life Balance?. Journal of Evidence-Based Psychotherapies, 16(1), 67-77.

Chakrabarty, S., Widing, R. E., \& Brown, G. (2014). Selling behaviours and sales performance: The moderating and mediating effects of interpersonal mentalizing. Journal of Personal Selling and Sales Management, 34(2), 112-122. DOI: 10.1080/08853134.2014.890899.

Chen, Y. H., Lin, T. P., \& Yen, D. C. (2014). How to facilitate inter-organizational knowledge sharing: The impact of trust. Information and Management, 51(5), 568-578. DOI: 10.1016/j.im.2014.03.007. 
Dijk, A. Van, Hendriks, P., \& Romo-leroux, I. (2016). Knowledge sharing and social capital in globally distributed execution. Journal of Knowledge Management. 20(2), 327-343. DOI: 10.1108/JKM-07-2015-0268.

Donate, M. J., \& de Pablo, J. D. S. (2015). The role of knowledge-oriented leadership in knowledge management practices and innovation. Journal of Business Research, 68(2), 360-370. DOI: 10.1016/j.jbusres.2014.06.022.

Elias, A. A., \& Davis, D. (2018). Analysing public sector continuous improvement: a systems approach. International Journal of Public Sector Management, 31(1), 2-13. DOI: 10.1108/IJPSM-08-2016-0135.

Elmuti, D., \& Kathawala, Y. (1997). An overview of benchmarking process : a tool for continuous improvement and competitive advantage. Benchmarking for Quality Management \& Technology, 4(4), 229-243.

Faraj, S. (2005). Why Should I Share? Examining Social Capital and Knowledge Contribution in Electronic Networks of Practice. MIS Quartely, 29(1), 35-57.

Fryer, K. J., Antony, J., \& Douglas, A. (2007). Critical success factors of continuous improvement in the public sector A literature review and some key findings. The TQM Magazine, 19(5), 497-517. DOI: 10.1108/09544780710817900

Fryling, M. J., Johnston, C., \& Hayes, L. J. (2011). Understanding Observational Learning: An Interbehavioral Approach. The Analysis of Verbal Behavior, 27(1), 191-203. DOI: 10.1007/bf03393102

Ghozali, I. (2005). Aplikasi Analisis Multivariate dengan SPSS. Semarang: Badan Penerbit UNDIP.

Greenfield, E. A. \& Marks, N. F. (2007). Continuous Participation in Voluntary Groups as a Protective Factor for the Psychological Well-Being of Adults Who Develop Functional Limitations: Evidence From the National Survey of Families and Households. The Gerontological Society of America, 62(1), 60-68.

Hair, J. F., Sarstedt, M., Ringle, C. M., \& Mena, J. A. (2012). An assessment of the use of partial least squares structural equation modeling in marketing research. Journal of Academy of Marketing Research, 4O(3), 414-433. DOI: 10.1007/s11747-011-0261-6.

Haldin-Herrgard, T. (2000). Difficulties in diffusion of tacit knowledge in organizations. Journal of Intellectual Capital, 1(4), 357-365. DOI: 10.1108/14691930010359252

Heskett, J. L., Sasser, W. E., \& Schlesinger, J. L. A. (1997). The service profit chain: How leading companies link profit and growth to loyalty, satisfaction, and value. Weekly Library Science Databased, 8. DOI: 10.1108/ijsim.1998.9.3.312.3

Hew, K. F., \& Hara, N. (2007). Empirical study of motivators and barriers of teacher online knowledge sharing. Educational Technology Research and Development, 55(6), 573.

Holste, J.S. \& Fields, D. (2010). Trust and tacit knowledge sharing and use. Journal of Knowledge Management, 14(1), 128-140.

Hsu, I. C. (2008). Knowledge sharing practices as a facilitating factor for improving organizational performance through human capital: A preliminary test. Expert Systems with Applications, 35(3), 1316-1326.

Inkpen, A. C., \& Tsang, E. W. K. (2005). Social Capital, Networks, and Knowledge Transfer. The Academy of Management Review, 301), 146-165. DOI: 10.2307/20159100

Islam, M. Z., Jasimuddin, S. M., \& Hasan, I. (2015). Organizational culture, structure, technology 
infrastructure and knowledge sharing. Vine, 45(1), 67-88. DOI: 10.1108/VINE-05-20140037.

Itani, O. S., \& Inyang, A. E. (2015). The effects of empathy and listening of salespeople on relationship quality in the retail banking industry. International Journal of Bank Marketing, 33(6), 692-716. DOI: 10.1108/IJBM-06-2014-0076.

Kara, A., Andaleeb, S. S., Turan, M., \& Cabuk, S. (2013). An examination of the effects of adaptive selling behavior and customer orientation on performance of pharmaceutical salespeople in an emerging market. Journal of Medical Marketing, 13(2), 102-114. DOI: $10.1177 / 1745790413488779$

Kaynak, E., Kara, A., Chow, C. S. F., \& Laukkanen, T. (2016). Role of adaptive selling and customer orientation on salesperson performance: Evidence from two distinct markets of Europe and Asia. Journal of Transnational Management, 21(2), 62-83. DOI: 10.1080/15475778.2016.1166999

Khan, M. S., Breitenecker, R. J., \& Schwarz, E. J. (2015). Adding fuel to the fire: Need for achievement diversity and relationship conflict in entrepreneurial teams. Management Decision, 53(1), 75-99. DOI: 10.1108/MD-02-2014-0066

Kumar, N., \& Rose, R. C. (2012). The impact of knowledge sharing and Islamic work ethic on innovation capability. Cross Cultural Management, 19(2), 142-165. DOI: 10.1108/13527601211219847

Leischnig, A. and Kasper-Brauer, K. (2015). Employee adaptive behavior in service enactments, Journal of Business Research, 68(2), 273-280. DOI: 10.1016/j.jbusres.2014.07.008.

Limbu, Y. B., Jayachandran, C., Babin, B. J., \& Peterson, R. T. (2016). Empathy, nonverbal immediacy, and salesperson performance: the mediating role of adaptive selling behavior. Journal of Business and Industrial Marketing, 31(5), 654-667. DOI: 10.1108/JBIM-03-20150048

Lin, C., \& Lin, C. (2007). To Share or Not to Share: Modeling Tacit Knowledge Sharing , Its Mediators and Antecedents. Journal Business Ethics, 70(40), 411-428. DOI: 10.1007/s10551-006-9119-0

Lindgren, H. C. (1976). Measuring Need to Achieve by N Ach-N Aff Scale-A Forced-Choice Questionnaire. Psychological Reports, 39(3), 907-910.

Ling, C. T. N. (2011). Culture and trust in fostering knowledge-sharing. Electronic Journal of Knowledge Management, 9(4), 328-339. DOI: 10.1057/kmrp.2011.37

Luu, T. (2014). Knowledge sharing and competitive intelligence. Marketing Intelligence \& Planning, 32(3), 269-292. DOI: 10.1108/MIP-05-2013-0077

Mitchell, T., Hekman, D. R., Holtom, B. C., Cook, W. S., Mitchell, T. R., Lee, T. W., \& Harman, W. S. (2009). Turnover Contagion: How Coworkers' Job Embeddedness and Job Search Behaviors Influence Quitting. Academy of Management Journal, 52(3), 545-561. DOI: 10.5465/AMJ.2009.41331075

Mosala-Bryant, N.N. \& Hoskins, R.G. (2017). Motivational theory and knowledge sharing in the public service. South African Journal of Information Management, 19(1), 1-9, DOI: 10.4102/ sajim.v19i1.772

Murtaza, G., Abbas, M., Raja, U., Roques, O., Khalid, A., \& Mushtaq, R. (2016). Impact of Islamic Work Ethics on Organizational Citizenship Behaviors and Knowledge-Sharing Behaviors. Journal of Business Ethics, 133(2), 325-333. DOI: 10.1007/s10551-014-2396-0 
Nahapiet, J. (2013). Capital, social capital, intellectual advantage and the organizational. The Academy of Management Review, 23(2), 242-266.

Ng, K. Y. E. E. (2005). Antecedents and Performance Consequences of Helping Behavior: A Multilevel Analysis. Group \& Organization Management, 30(5), 514-540. DOI: $10.1177 / 1059601104269107$

Nonaka, I., \& von Krogh, G. (2009). Perspective-Tacit Knowledge and Knowledge Conversion: Controversy and Advancement in Organizational Knowledge Creation Theory. Organization Science, 20(3), 635-652. DOI: 10.1287/orsc.1080.0412

Nunnally, J.C. \& Bernstein, I.H. (1994). Psychometric Theory (3 rd Edition). McGrawHill Series in Psychology, McGraw-Hill, Inc., New York: NY, 264-265.

Obeidat, B. (2015). Knowledge Sharing Capability: A Literature Review. Journal of Business \& Management, 4(1), 1-13.

Olowookere, E. I., \& Adekeye, O. A. (2016). Relationship between Religiosity and Citizenship Behaviours in Organizations: Empirical Evidence from Selected Organisations in Lagos State. Mediteranean Journal of Social Science, 7(4), 475-484. DOI: 10.5901/mjss.2016.v7n4p

Orces, S. O. S. F., \& Kim, Y. (2005). Behavioral Intention Formation in Knowledge Sharing: Examining the Role of Extrinsic Motivators, Social-Psychological Forces, and Organizational Climate Knowledge Sharing: Examining The Roles Of Extrinsic Motivators. MIS Quartely, 29(1), 87-111. DOI: 10.2307/25148669.

Pathirage, C. P., Amaratunga, D. G., \& Haigh, R. P. (2007). Tacit knowledge and organisational performance: construction industry perspective. Journal of Knowledge Management, 11(1), 115-126. DOI: 10.1108/13673270710728277

Pinjani, P., \& Palvia, P. (2013). Trust and knowledge sharing in diverse global virtual teams. Information and Management, 50(4), 144-153. DOI: 10.1016/j.im.2012.10.002

Rosendaal, B. (2009). Sharing Knowledge, Being Different and Working as a Team. Knowledge Management Research \& Practice, 7(1), 4-14.

Saxe, R., Weitz, B. a, \& Weitz, A. (1982). A measure of the customer orientation onf salespeople. American Marketing Association, 19(3), 343-351.

Singh, R., \& Venugopal, P. (2015). The impact of salesperson customer orientation on sales performance via mediating mechanism. Journal of Business and Industrial Marketing, 30(5), 594-607. DOI: 10.1108/JBIM-08-2012-0141

Song, J. (2014). Subsidiary absorptive capacity and knowledge transfer within multinational corporations. Journal of International Business Studies, 45(1), 73-84. DOI: 10.1057/jibs.2013.55

Soyer, R. B., Rovenpor, J. L., \& Kopelman, R. E. (1999). Narcissism and Achievement Motivation as Related to Three Facets of The Sales Role: Attraction, Satisfaction and Performance. Journal of Business and Psychology, 14, 285-305.

Swift, M., Balkin, D. B., \& Matusik, S. F. (2010). Goal orientations and the motivation to share knowledge. Journal of Knowledge Management, 14(3), 378-393. DOI: $10.1108 / 13673271011050111$

To, W. M., Martin, E. F., \& Yu, B. T. W. (2015). Effect of management commitment to internal marketing on employee work attitude. International Journal of Hospitality Management, 45, 14-21. DOI: 10.1016/j.jhm.2014.11.002 
Wamitu, S. N. (2015). Tacit Knowledge Sharing in Public Sector Departments in Kenya. Open Journal of Business and Management, 3(1), 109-118.

Wang, W. T., \& Hou, Y. P. (2015). Motivations of employees' knowledge sharing behaviors: A selfdetermination perspective. Information and Organization, 25(1), 1-26. DOI: 10.1016/j.infoandorg.2014.11.001

Ward, Mi. R., \& Dranove, D. (1995). The Vertical Chain of Research and Development in the Pharmaceutical Industry. Economic Inquiry, 33(1), 70-87. DOI: 10.1111/j.14657295.1995.tb01847.x

Wong, A., Liu, Y., \& Tjosvold, D. (2015). Service leadership for adaptive selling and effective customer service teams. Industrial Marketing Management, 46, 122-131. DOI: 10.1016/j.indmarman.2015.01.012

$\mathrm{Wu}$, S. (2007). The influence of personal character on information communication and activity effect. Marketing Intelligence \& Planning, 25, 746-771. DOI: 10.1108/02634500710834205

Yang, J., Gong, Y., \& Huo, Y. (2011). Proactive personality, social capital, helping, and turnover intentions. Journal of Managerial Psychology, 26(8), 739-760. DOI: $10.1108 / 02683941111181806$

Yen, Y. X., Wang, E. S. T., \& Horng, D. J. (2011). Suppliers' willingness of customization, effective communication, and trust: A study of switching cost antecedents. Journal of Business and Industrial Marketing, 26(4), 250-259. DOI: 10.1108/08858621111126992

Yesil, S., \& Dereli, F. (2013). An empirical investigation of the organisational justice, knowledge sharing and innovation capability. Technology and Inovation Management, 75, 199-208. DOI: 10.1016/j.sbspro.2013.04.023

Yoon, S. W. (2016). Transformational leadership and knowledge sharing. Journal of Workplace Learning. DOI: 10.1108/JWL-09-2015-0066

Yu, Y., Hao, J. X., Dong, X. Y., \& Khalifa, M. (2013). A multilevel model for effects of social capital and knowledge sharing in knowledge-intensive work teams. International Journal of Information Management, 33(5), 780-790. DOI: 10.1016/j.ijinfomgt.2013.05.005

Zagenczyk, T. J., Scott, K. D., Gibney, R., Murrell, A. J., \& Bennett, J. (2010). Organizational Behavior and Human Decision Processes Social influence and perceived organizational support: A social networks analysis. Organizational Behavior and Human Decision Processes, 111(2), 127-138. DOI: 10.1016/j.obhdp.2009.11.004

Zahrah, N., Norasyikin, S., Hamid, A., Huda, S., \& Rani, A. (2016). Enhancing Job Performance through Islamic Religiosity and Islamic Work Ethics. International Review of Management and Marketing, 6, 195-198.

Zhanga, Y., \& Begleyb, T. M. (2011). Perceived organisational climate, knowledge transfer and innovation in China-based research and development companies. International Journal of Human Resource Management, 22(1), 34-56. DOI: 10.1080/09585192.2011.538967 